\title{
Civilized and wild heterotopia - the case of the Polish cemeteries
}

\section{DOI: $\underline{\text { http://doi.org/10.26758/8.1.27 }}$}

\author{
Anna E. Kubiak
}

Institute of Philosophy and Sociology, Polish Academy of Sciences

Address correspondence to: Anna E. Kubiak, Institute of Philosophy and Sociology, Polish Academy of Sciences, Nowy Świat 72, Pałac Staszica, 00-330 Warszawa. Ph.: (48 22) 8267181; Fax: (48 22) 8269948; E-mail: akubiak@ifispan.waw.pl

\begin{abstract}
Objectives. The main goal of this paper is to present the characteristic features of Polish cemeteries as a unique expression of Polish traditions. The Poles have strong and ritually supported bonds with their ancestors.

Material and methods. In 2010-2012, I interviewed funeral directors, some of whom were also cemetery managers. Qualitative methods were employed in the form of semi-structured interviews. I also analyzed the journals Memento and Kultura Pogrzebu (Funeral Culture) produced by funeral institutions. Content analysis of the ethnographic and popular literature on Polish cemeteries was followed by the identification of the characteristic features of Polish necropolises, those that are unique to Polish culture.

Results and Conclusions. The Poles are devoted to preserving the past which they find in cemeteries. They cultivate social bonds with their families and Polish heroes while visiting necropolises and talking with the dead. I propose the model of opposition between civilized and wild heterotopy. We can talk about two types of necropolis in Poland: civilized heterotopy (which is Polish classic cemetery) and wild heterotopy. Wild heterotopy can be found in forests or groves. There are places with unwanted (e.g., Germans, Jews) and forgotten dead (e.g., Old Believers).
\end{abstract}

Keywords: cemetery; archive; memory; social bonds; heterotopy.

\section{Introduction}

The main goal of this article is to present the characteristic features of Polish cemeteries as a unique expression of Polish traditions and national identity. Robert P. Harrison, in the introduction to his The Dominion of the Dead (2003, p. xi), suggests that "humanity is not a species (Homo sapiens is a species); it is a way of being mortal and relating to the dead. To be human means above all to bury." He goes on to argue, quoting Giambattista Vico, that the word humanitas is derived from humando, "burying." To be human means above all to bury. Burial means not only laying the body in the grave but, in a broader sense, relates to preserving, protecting, and cultivating the past. In The Work of the Dead (2015) Thomas Laqueur analyses how a complex mix of factors including concern with public health, the waning power of the Catholic Church, and the emergence of a belief that the place where one is buried should be a matter of personal choice - produced a shift whereby necropolises supplanted the church graveyard as the chief place of interment. He describes how sites were created in which the dead were separated from the living as they had not been when they were interred in or near places of worship. With the rise of cemeteries, the dead 
could be remembered as individuals and buried with their families in a way that was impractical in overcrowded churchyards. He writes that no culture has been indifferent to mortal remains. Even in our late modern time, the dead body still matters - for individuals, communities, and nations. These words aptly describe Polish commemorative culture.

After presenting methods, the importance of necropolis in the Polish commemorative culture is shown. Then follows an analysis of cemeteries in the context of Foucault's notion of heterotopia, which is further followed by examples of historic necropolises. The problem of postwar graveyards is discussed in esthetic terms. Then the case of some of necropolises of faiths other than Roman Catholicism in the proposed category of wild heterotopia in opposition to civilized heterotopia is analyzed.

\section{Material and methods}

During 2010-2012, undertakers and cemetery managers were interviewed about the crucial problems of the funeral industry and necropolises. Qualitative methods were employed in the form of semi-structured interviews. In 2010-2012 the content of the journals Memento and Kultura Pogrzebu (Funeral Culture) produced by funeral institutions were also analyzed. Memento was founded in 1995 by Wojciech Krawczyk, a journalist and an enthusiast of death-related issues and is published every 2 months by the Polish Funeral Association. The Funeral Culture magazine was founded in 2004 by an undertaker and is associated with the Polish Funeral Chamber. Recipients of magazines are undertakers, producers of burial facilities and graveyard managers. Both magazines have a rich layout and upload numerous photographs of funeral homes, manufacturing companies, artifacts, hearses, graveyards and undertakers on the occasion of the training and the fair. Both journals present cemeteries in Poland and necropolises from abroad. Also, legal procedures of cemeteries and burials are discussed. Content analysis of the ethnographic and popular literature on Polish cemeteries was also conducted in order to identify the characteristic features of Polish necropolises, those unique to Polish culture.

\section{Results}

Elsewhere (Kubiak, 2014) the most characteristic features of this culture were identified: mourning, strong bonds with ancestors, myths of tribal catastrophes and the achievements of heroes. The main rituals take place in the sacral spaces of ancestor cults. The topoi of the mythic narrations are death, suffering, communication with heroes and ancestors, and bloody sacrifices. The Poles have strong and ritually supported bonds with their ancestors. Cemeteries are often visited, obligatorily on All Saints' Day, Christmas and Easter. The graves are carefully cleaned and decorated with garlands, flowers, and candles. All Saints' Day together with All Souls' Day is the most collective holiday in the public space. For a long time before the holiday, markets are full of ever-burning fires. One cannot forget about the approach of All Saints' Day because mourning flowers - chrysanthemums - and flames can be seen everywhere: when buying newspapers from newsstands, on the streets, in squares, and in supermarkets. The Poles collectively go to the cemeteries. Bringing candles and flowers to graves and meeting with families and friends is part of the process of affirming social bonds among the living and between the living and the dead. During these days, bus and train lines change routes to the necropolises. The police, under the banner of "the ever-burning fire," try to prevent traffic jams and accidents. Poles independently of their structural characteristics, such as the age or socio-economic position follow this tradition. The spirit of this holiday is very well expressed by Paul Allen (2008, p.15): "This ceremony performed in the 
smallest village and in the biggest city defines what it means to be the Pole. This is the pilgrimage, which cannot be avoided. The consciousness who they are, the Poles owe to the strong belief that on All Saints Day the ancestors speak beyond the grave".

As Michel Foucault has taught us, the category of space is one of the basic notions. Space is - unlike time - still heterogenic and cannot be reduced to something else. Heterotopia is, in a way, an unreal, peculiar, odd place. It differs "in an absolute way from all other places" and is "sort of contre-emplacements" (Foucault, 2005, p.120), contesting and dislocating the order of other places. A cemetery is a classic heterotopia. As a sacral space, this heterotopia is isolated, surrounded by a fence and with a special entrance: the gate. The Polish anthropologist Stefan Czarnowski (1956) stated that every religious unit is a space isolated from the rest. It consists of the middle, the border and the space between them. In the middle and on the border are the greatest levels of intensity of holiness. In the middle of the cemetery, as a sacred space, there is a cross or a chapel which is, according to Czarnowski, opened toward the vertical - heaven. It has been the most desired place for burial (Sikora, 1986, p.60). On the borders, in one particular corner, dangerous people were buried: unbaptized children, suicides, Jehovah's Witnesses, and unbelievers (Sikora, 1986, p.60), which is not the case anymore. The cross of borders has the greatest intensity of power. What kind of power? The word sacer means holy and damned at the same time (Sikora, 1986, p.60). This ambivalent character of the religious space has been underlined by phenomenological anthropologists like Mircea Eliade (1970) or Gerardus van der Leeuw (1978). In this unhallowed corner were the dead who will go to hell or become extraterritorial and wander around as demons (Sikora, 1986, p.60).

Cemeteries were absorbed by the city as it expanded and the risk of epidemics disappeared. So now it is the Other City - the City of the Dead (as it is used to say in Poland) - in the city. In Polish tradition, tombs are treated like houses and the coffin is named "overcoat." While visiting the cemetery, people talk with their ancestors. The director of Powązki, the Warsaw cemetery, says, "There comes the moment in a human's life when he starts to care and plan for his tomb, as for the house before. Today nobody wants to have an earth tomb, everybody wants to have brick, with a monument. The best is from granite to preserve it for a long time. Important are the place, the quarter and the neighbors" (Sikora, 1986, p.57).

One of the roles of a heterotopia mentioned by Foucault (2005) is its historic importance as an archive. The cemetery is an archive of symbolically important times of war, catastrophe, and so on. In Poland, the dead are very mobile. There is a special category of "exhumans" (exhumed persons) who change their location. There are "exhumans" coming back from abroad and being welcomed with enthusiasm. Corpses are very useful for the "politics of dead bodies" described by Katherine Verdery (1999), a question of private and collective memory which an object of political manipulation is also. In Polish the word: tomb - pomnik - is connected to the word memory pamięć. The role of memory is repeated often in the discourse of cemeteries and the Day of the Dead (All Saints' Day and All Souls' Day) - the most public holiday in Poland. The word pamiatka (remembrance) appears often in epitaphs on tombs. There is the tradition, now undergoing a revival, of memorial tomb photography. It is a sign of the importance of family memory. Most of the photographs have an ellipse shape which corresponds to the form of imago clipeata (an ellipse shape), characteristic of coffin portraits (Kubiak, 1986).

The funeral journals present the best examples of Polish historical cemeteries as places of Polish heritage, collective memory, and national identity. The authors of the articles underline the devotion of Poles to preserve and renovate them. The most famous necropolis is the Central Cemetery in Szczecin. It is the cemetery with the biggest variety of graves, from well-preserved old tombs to new designs. It is the biggest necropolis in Poland and the third largest in Europe. It has 
won the award in a competition organized by the National Geographic Traveler for seven "miracles" in Poland. Officially opened in 1901, it took its design from the necropolises in Hamburg and Vienna. It occupies 172 hectares and includes 400 types of trees and shrubs (Wolicki, 2011, p. 10). The project was prepared by the architect Wilhelm Meyer-Schwartau, who included the natural landscape: hills, stones and water flows. There is a botanical pathway through the most interesting natural features. The tourist guide features a description of flora with references to their symbolism: yew in Celtic tradition symbolizes the gate to the other world, the box means hope of resurrection and eternity, hornbeam is identified with care, ilex is the symbol of the Christmas holiday, ivy relates to the memory of the dead. There are representations of wild animals: birds, foxes, raccoons, badgers, hares, hedgehogs, red squirrels, wild boar, frogs, snakes and wild ducks. Owing to the manager of the cemetery, Maria Michalak, who is devoted to her work, lapidarium has been laid. It is a place where German tomb relics are gathered and renovated. In the interview she said:

"There are quite a few remains of the German, that I rescue and still think, that it is what I saved from oblivion and I admire what was before us, that is, prior to this period, when the cemetery was taken over (by the Polish communist regime - AEK). And, you know, I assert with all the responsibility that the designers of this cemetery were phenomenal. Today no cemetery, none, I emphasize, with full responsibility, there is no such message, such a vision of the perspective of such thinking forward. Here everything is thought out in detail" (The interview no. 16).

Powązki, the oldest cemetery in Warsaw, was founded in 1790. It was enlarged 19 times and now includes 43 hectares. More than 2.5 million people have been buried there (Danecka, 2010, p. 34). It was devastated during the Second World War and for a long time only paths, greenery, water and electric structures were renovated. In 1974, a social committee was founded by the writer Jerzy Waldorf and some famous actors, among others. Every year, during All Saints' Day, they organize collections: actors stand by the gates with cans and people donate with enthusiasm. For Warsaw inhabitants, visiting Powązki is a popular ritual, even if relatives are buried elsewhere.

The Old Cemetery in Rzeszów was founded in 1792 and has been abandoned twice: during the Second World War and when the Communist authorities decided to close it and a fighting squad destroyed many tombs, which were used as building material for roads. A passionate group of volunteers committed to preserving cultural heritage, with Włodzimierz Kozło as their leader, sought to save the cemetery. Owing to their work, the necropolis was registered as a relic in 1968. But only political changes helped to speed the conservation process and, in 2001, the Society of Care over the Old Cemetery was founded. They took care of the old stands of trees and sepulchral sculpture. The Old Cemetery occupies 365 hectares and includes 622 tombs. Many of its sculptures come from the famous Schimser Lwow atelier. There are examples of historical styles such as classicist and Neo-Gothic, and some sculptures feature heraldic arms and stone figures (Kałuszko, 2011a, pp.34-36).

One of the oldest necropolises in Poland is the Roman Catholic cemetery in Radom. It was founded in 1812 and more than 200 people were buried there. Once again, through the efforts of cultural workers and pupils, who were educated in restoration techniques and conducted descriptive and photographic inventories, the cemetery has been renovated. The main source of financing comes from social donations, which are a Polish custom during the Day of the Dead. The cemetery at Radom preserves 335 objects registered as historical relics (Kałuszko, 2011b, pp. 24-26). The renovation of cemeteries is understood as necessary to the preservation of the nation's heritage. Historical necropolises are reminiscent of art galleries in which sepulchral sculptures and green relics compose the art space. 
Benjamin Franklin is supposed to have said, "Show me your cemeteries, and I will tell you what kind of people you are" (West Virginia Arnold Hill Cemetery Association, 2013). Polish undertakers notice positive changes in the Polish cemeteries since the 90s. Here are some illustrative fragments from the interviews:

"The change is also that almost everyone has the tombstone. At the moment people like monuments and take care of them because it is publicly exposed. It is the difference between a cemetery before fifty years and today" (The interview with the undertaker no. 12).

"But I have to tell you, that how I look in retrospect, these cemeteries are increasingly cared for, even these smaller cemeteries. Some have cheaper monuments but they are gravestones and they will survive years. These cemeteries are getting nicer. People bring lots of flowers and other decorations. Once on the villages, who walked to the cemetery after the funeral? Before All Saints, possibly some during kind of anniversary and that is all. But nowadays in the countryside cemeteries are not different from the city. That is changing" (The interview with the undertaker no. $35)$.

The look of the necropolis depends on the culture and its system of values. These have their consequences in cemetery law. Since 1846, when the regulation governing cemeteries was founded by the administration of the Polish Kingdom during the rule of Tsar Nicolay I (Długozima, 2011b, p. 15), cemetery managers have had to take care of the aesthetic dimensions of the necropolis. The present Polish law on cemeteries and the legal mandate for the deceased dates from 1959 and duplicates provisions enacted even earlier, in 1932. There are around 20 new legislative acts, so the rules are dispersed. There is a regulation mandating that cemeteries should be treated like parks. But this is only the intention of the legislator. While the Nature Protection Act keeps historic cemeteries safe, those not covered by conservation rules are at the mercy of officials at the lowest level. Upkeep decisions are often left to a parish priest, supported by inhabitants who are more interested in the practical aspects of cleaning (no leaves and bird excrement) than in caring for greenery and making sure trees are pruned. In new cemeteries, this greenery is often neglected, and there is a fatal practice of Polish managers leveling the ground instead of preserving the natural layout of the area (Długozima, 2011a, p.17). Although research into the natural environment is legally mandated when planning a new cemetery, it is not legally required that the results be implemented when developing necropolis projects (Długozima, 2011b, p. 40). Until the Second World War, there were many specialists in cemetery projects. Now new necropolises are kitschy and identical, because of limited choice and of the prize of tombstones. So many people choose lastric tombs in 80-ties and now ready-made tombs from China (Długozima, 2011c, pp.17-19). Owing to the initiative of Anna Długozima and the foundation of the Sepulchral Art Section at the Department of Landscape Art at the Main School of the Village Farm in Warsaw, there are efforts underway to change this and propose alternatives to serial, standard patterns both in greenery and monuments.

Funeral press criticizes cheap tombstones and decorations from popular culture: "In the historic cemeteries in Warsaw and other cities, between old tombs, which often were designed by great artists, the tombstones from the Chinese marble or other stone, in the shape of a simple disc equipped at the top of the vertical surface in the shape of a wave began to appear in the recent years. There are many of them. It is hardly surprising because they are relatively cheap. People gifted with aesthetic sensibility are not able to come to terms with the fact that these monsters with impunity are penetrating the mood of the necropolis, to stand right next to the beautiful sculptures of the 19th century" (Memento 2010, no.3, p.12). 
"Unfortunately, the free market also leads to unhealthy competition that results in progressive kitsch cemetery ornaments. Popular are also candles with LED. You do not have to light up matches any longer. Steel flower, colorful granite and marble, liquid crystal display screen and plaster figurines, music boxes and letters only golden. This is the shortest list of pervasive, cemetery kitsch" (Funeral Culture 2012, no 8, p 12).

The editors of both journals: Memento and Funeral Culture try to promote positive patterns through presenting old Polish necropolis, as well as presentations of Polish artists of the sepulchral, commemorative, vanitative and floristic art. Memento also posted the text of the outcome of the contest of modern tomb, organized by the Office of Capital Historic Preservation and Polish Architects Association. The problem of the esthetic of postwar cemeteries has been also the permanent topic of complaints among funeral directors and cemetery managers. One of them said:

„Here, for example, this cemetery (the Central Cemetery in Szczecin) was founded in the unspoilt former gravel workings. This inequality was used perfectly on-the-spot, to the cemetery to spice things up, to not close out various lakes, various terraces, bleeds, descend, paths. This is fantastic. And what we today we do when we design a larger cemetery? First of all, we focus on leveling the terrain. This is a huge mistake" (The interview no. 16).

In Poland, there are also necropolises of faiths other than Roman Catholicism: Evangelical-Augsburg (Lutheran), Orthodox, Jewish, Old Believers, Protestant, Mnemonic, Greek Orthodox and Tatars. The Jewish cemetery in Łódź is the largest Jewish cemetery in Europe. There are approximately 180,000 tombstones. The cemetery was founded in 1892. In the southern part of the cemetery can be found the field of the ghetto - the burial place of about 45,000 victims of the Litzmannstadt Ghetto.

More than four hundred Jewish cemeteries have not survived. They have been developed for housing, playgrounds, landfill or mine sand. "Sand, used in the construction of apartment blocks is mixed with human remains," according to Mikołaj Gliński (2013). Only 150 Jewish cemeteries contain more than one hundred tombstones. Jewish tombstones decorated with symbols and inscriptions carry with them information about the lives of actual people and families. It is difficult to estimate how many matzevot (Jewish tombstones) existed before the Second World War in the 1,200 Jewish cemeteries in Poland. Maybe a few hundred thousand, maybe a few million. During the war, the German occupiers used them to pave roads and the yards occupied by buildings. The Poles continued these practices after the war. They used them to pave a railway embankment or the shore of a river. They used them to build ovens, floors, curbs. In the Polish villages you can find hundreds of grinding wheels made of Jewish tombstones. Still, you can see in them the Hebrew inscriptions. An album by Łukasz Baksik (2013) includes photographs of such multipurpose matzevot in Polish villages and in the cities. These are the gravestones as paving slabs and curbs, as querns (used for grinding grain to make bread), as a wall, as stairs, as hardened roads - in the end, they were repurposed as Christian tombstones. These missing gravestones Baksik found located in the backyards of farms, in town squares, within the walls of Christian cemeteries, in buildings, barns, as building blocks of bridges, towers, monuments. To photograph these often heavily camouflaged matzevot he had to break the taboo of the community - "a community of shame," as Joanna Tokarska-Bakir says (Glinski, 2013). "I am surprised by this stealing from the cemeteries. Not only because the sandstone, from which generally gravestones are made, is a weak building material. After all, it is also, for Poles, for Catholics, a sacred thing. We are enraged about when someone will devastate the Eaglets' Lwow Cemetery, tip over a headstone or a cross. And in the matter of the Jewish necropolis we are completely insensible," says Baksik (Glinski, 2013). His 
photographs document how far advanced is the obliteration of all traces of Jewish culture, not only by the Germans, but also Poles. "Trying to understand this lack of indignation at the sight of all these different places and new uses of matzevot he wonders whether these scattered gravestones Poland do not travel in the search for the dead and there are, where Baksik photographed them, as it were, in the right place? [...] So I guess it must be that the dead, who have not been decently buried, wander among the living, not giving them peace," says Jan Tomasz Gross and continues, "Until finally, the time comes when we tell ourselves this human disaster as part of our own history. And in place of complacency and its benefits will come the understanding of loss and a mourning sadness in the collective consciousness of the Poles. And then the war nightmares' torment will stop, and the gravestones photographed by Baksik return to the cemeteries" (Glinski, 2013).

Old Believers, called also Filippians, left Russia in the $17^{\text {th }}$ century because they were in conflict with the Orthodox Church and so were exiled to Sybir. Many of them settled down in Mazury in the first half of the $19^{\text {th }}$ century, about five thousand of them near Suwałki and some near Ruciane-Nida. Their main religious center was in Wojnowo, where there is still a molenna - the house of prayer. In 1945 the Red Army exiled them to Sybir and some migrated to Germany. As I spend my vacations near Wojnowo, in Zgon (which means death in Polish), I became acquainted with several Old Believers' graveyards and one German cemetery in Zgon which are neglected and hard to find in the forest. As Old Believers had never been the part of the local community, so they are still considered non-people. They can be forgotten and their cemeteries are omitted. Germans are remembered as aggressors and inhabitants don't want to take care of Evangelic graveyard.

\section{Conclusions}

The cemetery described by many ethnographers and historians as the space of sacrum, cultural heritage, memory, and identity is particularly relevant in the case of Polish cemeteries. They have a special status and canon of behavior. The Poles are devoted to preserving the past which they find in cemeteries. They cultivate social bonds with their families and Polish heroes while visiting necropolises and talking with the dead. But the examples of graveyards on post-migrant territories of Poland are contre-emplacements which display the importance who are the dead. Thus, this study proposes the model of opposition between cultivated and abandoned cemeteries. We can talk about two types of necropolises in Poland (there can be more typologies): civilized heterotopias and wild heterotopias.

Wild heterotopias are atopic places. They are absorbed by Nature. Here the border between culture and nature is blurred. Also the border between life and death - so well kept in civilized heterotopias - is blurred. Here we can expect a second life of the dead, or at least a second life of corpses. Looking for other metaphors of wild heterotopias, we can think about "places of nomemory," as described by Pierre Nora (2009). They are "no-places in the dialectics of memory and forgetting" (Czaja, 2013, p.302). We can also take into account Claude Lanzmann's description of such lost graveyards as non-places of memory. Even funeral journals and undertakers don't mention the problem of neglected necropolis. Georges Didi-Huberman (2012) writes about "places despite everything." There are rituals which are no-rituals performed by accidental tourists, men looking for a place to drink and conscious visitors like new people having summer houses and bringing and lighting the ever-burning fires. Their imagination surrounds these non-cemeteries with a special, symbolic aura. By local people these places are made active in the way that they are passed by, omitted - made the taboo places. Locals want to forget them - or, rather, not to remember them. These non-places recall also the Derridean notion of "chora" (1999). Giorgio Agamben refers to the notion of "hypostasis" as "something of the shape of the substrate, primers or sludge, what historical 
processes of subjectivation and de-subjectivation, humanization and dehumanization leave one after the other like the foundation of its development" (Agamben, 2008, p.159). It can be also called "post place," a place which after traumatic history has been lost and left and is taken in by the power of Nature. At the same time, it is the place which owing to "post memory" is enlivened, but "using Hirsch's (2008) words, in a 'substitutive and usurping way"' (Sznajderman, 2013, p.56). There is also the notion of "xenotropy" proposed by Robert Macfarlane (2013) for the strange places he met during his journeys. He had the feeling of entering into a completely different, separate world. Wild heterotopias can be found in forests or groves. There are places with unwanted (e.g. Germans, Jews) and forgotten dead (e.g., Old Believers).

China Miéville in the science fiction novel The City and the City (2009) describes two cities existing in one place. To live and move around, inhabitants have to learn how not to see, how to omit the space of the other city. Poles analogically cultivate commemorative memory of their dead but are educated not to see aliens' dead. As the cultural anthropologist Joanna Tokarska-Bakir (2013, p. 10) writes, they are trained to "actively avoid" the historical meanings of artifacts (images of a Jew with a coin) and places. Although collective memory simply renounces inconvenient stories that show the community in a "bad light" (such as using matzevot in a profane way), it does not eliminate them. Collective memory preserves traumas on deeper levels. These underground layers of memory are the equivalent of the "forgotten," lost in the landscape, "wild heterotopias." Fortunately, new, informal, local communities arise and start the process of revitalization of destructed cemeteries (Zawiła, 2017).

\section{Acknowledgments}

This research was supported by founding from the National Science Centre, grant no. 116081739.

\section{References}

1. Agamben, G., 2008. Co zostaje z Auschwitz (Remnants of Auschwitz). Warszawa: Sic!.

2. Allen, P., 2008. Amerykanin jedzie na Powązki (An American goes to Powazki). Gazeta Wyborcza, 31 Oct. - 2 Nov. (Feuilleton), p. 15.

3. Baksik, Ł., 2013. Macewy codziennego użytku (Matzevot of everyday use). Czarne: Wołowiec.

4. Czaja, D., 2013. Nie-miejsca. Przybliżenia, rewizje (Non-places). In: D. Czaja, ed. 2013. Inne przestrzenie, inne miejsca: Mapy i terytoria (Other Spaces, Other Places. Maps and Territories). Czarne: Wołowiec, pp.48-62.

5. Czaja, D. ed., 2013. Inne przestrzenie, inne miejsca: Mapy i terytoria (Other Spaces, Other Places: Maps and Territories). Czarne: Wołowiec.

6. Czarnowski, S., 1956. Kultura religijna wiejskiego ludu polskiego (Religious culture of the Polish folk). Warsaw: PWN.

7. Danecka, A., 2010. Coroczne kwesty ratunkiem dla zabytkowych Powązek (Every year donations save Powązki). Memento, 1, pp.34-35.

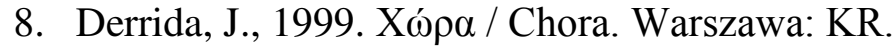

9. Didi-Huberman, G., 2012. Obrazy mimo wszystko (Images despite everything). Warszawa: Universitas.

10. Długozima, A., 2011a. Polska kontra reszta świata (Poland versus the rest of the world). Kultura Pogrzebu, 8, pp.14-17.

11. Długozima, A., 2011b. Prawodawstwo cmentarne na Zachodzie (Cemetery legislation of the West). Kultura Pogrzebu, 8, pp.40-41. 
12. Długozima, A., 2011c. Oryginalność made in China (Originality made in China). Kultura Pogrzebu, 7, pp 17-19.

13. Eliade, M., 1970. Sacrum mit historia (Sacrum myth history). Warszawa: PIW.

14. Foucault, M., 2005. Inne Przestrzenie (Different Spaces). Teksty Drugie, 6, pp.117-125.

15. Gliński, M., 2013. Łukasz Baksik, Macewy Codziennego Użytku (Matzevot of Everyday Use). Culture.PL [online]. Available at: http://culture.pl/pl/artykul/lukasz-baksik-macewycodziennego-uzytku [Accessed June 22, 2017].

16. Harrison, R.P., 2003. The Dominion of the Dead. Chicago: University of Chicago Press.

17. Hirsch, M., 2008. The Generation of Postmemory. Poetics Today, 1(29), pp.103-128.

18. Kałuszko, J., 2011a. Stary Cmentarz w Rzeszowie i jego obrońcy (Old Cemetery in Rzeszow and its defenders). Kultura Pogrzebu, 10, pp.33-36.

19. Kałuszko, J., 2011b. Stary Cmentarz ma opiekunów (Old cemetery has guardians). Kultura Pogrzebu, 11, pp.24-27.

20. Kubiak, A.E., 2014. Inne śmierci: Antropologia umierania i żałoby $w$ późnej nowoczesności (Other deaths: Anthropology of dying and mourning in late modernity). Warszawa: Universitas.

21. Kubiak, K., 1986. Wokół fotografii nagrobnej (Around tombstone photography). Polska Sztuka Ludowa, 1-2, pp.69-82.

22. Laqueur, T.W., 2015. The Work of the Dead: A Cultural History of Mortal Remains. Princeton: Princeton University Press.

23. Macfarlane, R., 2013. The Old Ways. A Journey on Foot. London: Penguin.

24. Miéville, C., 2009. The City and the City. London: Macmillan.

25. Nora, P., 2009. Między pamięcią i historią (Between memory and history). Archiwum, 2, pp.412.

26. Sikora, S., 1986. Cmentarz: Antropologia pamięci (Cemetery: The anthropology of memory). Polska Sztuka Ludowa, 1-2, pp.57-68.

27. Sznajderman, M., 2013. Przerwy w pamięci: Historia rodzinna (Interactions in memory: Family history). In: D. Czaja, ed. 2013. Inne przestrzenie, inne miejsca: Mapy i terytoria (Other Spaces, Other Places: Maps and Territories). Czarne: Wołowiec. P. 56

28. Tokarska-Bakir, J. Żyd z pieniążkiem (Jew with coin). In: J. Tokarska Bakir, ed. 2013. Tożsamość wyobrażona (Imagined identity). Warszawa: Czarna Owca. p.10

29. Van der Leeuw, G., 1978. Fenomenologia religii (Phenomenology of religion). Warszawa: Książka i Wiedza.

30. Verdery, K., 1999. The Political Lives of Dead Bodies: Reburial and Postsocialist Change. New York: Columbia University Press.

31. Wolicki, K., 2011. Cudowny Cmentarz (Miraculous Cemetery). Kultura Pogrzebu, 10, pp.1011.

32. Zawiła, M., 2017. Cemeteries revitalized by local communities - local communities revitalized by cemeteries in the post migrant territories of Poland. A mutual relation of heritage and society Paper presented 5th workshop conference of Architecture, Archaeology and Contemporary City Planning (AACCP), Turku, 15-18 May

33. ***West Virginia Arnold Hill Cemetery Association, 2013. History of Arnold Hill Cemetery [online]. Available at: http://www.rootsweb.ancestry.com/ wvahca/history.htm [Accessed January 22, 2017]. 